Summer 2015

\title{
Maintaining the Balance of Power: A Typology of Primacy Clauses in Federal Systems
}

\section{Brady Harman}

Indiana University, bharman@indiana.edu

Follow this and additional works at: https://www.repository.law.indiana.edu/ijgls

Part of the Constitutional Law Commons, and the International Law Commons

\section{Recommended Citation}

Harman, Brady (2015) "Maintaining the Balance of Power: A Typology of Primacy Clauses in Federal Systems," Indiana Journal of Global Legal Studies: Vol. 22 : Iss. 2 , Article 14.

Available at: https://www.repository.law.indiana.edu/ijgls/vol22/iss2/14

This Note is brought to you for free and open access by the Law School Journals at Digital Repository @ Maurer Law. It has been accepted for inclusion in Indiana Journal of Global Legal Studies by an authorized editor of Digital Repository@Maurer Law. For more information, please contactrvaughan@indiana.edu.

\section{$\Psi$}

JEROME HALL LAW LIBRARY

INDIANA UNIVERSITY

Maurer School of Law
Bloomington 


\title{
Maintaining the Balance of Power: A Typology of Primacy Clauses in Federal Systems
}

\author{
BRADY HARMAN ${ }^{*}$
}

\begin{abstract}
Constitutional design has become a novel and globalized legal profession. As such, practitioners in this new field-advisers and consultants of constitutional formation and reformation processesrequire practical and comparative tools to ply their trade. This Note attempts to fill a gap in constitutional design literature and provide such a tool by methodically examining "primacy clauses." By determining whether national or provincial law prevails when the two are in conflict, primacy clauses play an important role in maintaining federal balances of power. Three primacy approaches are found among the world's federal constitutions: national primacy, provincial primacy, and conditional primacy. This Note explores example constitutions for each approach and discusses possible effects each approach may have on power balances. Preliminary examinations suggest that conditional primacy may be more sensitive to the underlying reasons for original divisions of power between government levels; therefore, the conditional approach may be worth further exploration as a more effective and flexible approach to primacy.
\end{abstract}

* Brady Harman, Executive Production Editor, Indiana Journal of Global Legal Studies, Volume 22; JD 2015 Indiana University Maurer School of Law; MPA 2015 Indiana University School of Public and Environmental Affairs; BA, BS 2011 Indiana University-Purdue University Indianapolis. I would like to thank David C. Williams for suggesting the topic of this article and for his invaluable guidance throughout the process. I would also like to express my deepest gratitude to the students of the Center for Constitutional Democracy for sharing their stories and opening my eyes to the need for constitutional reform. Finally, I would like to thank the staff of the Center for teaching me that one can and must remain idealistic when attempting to address the systemic social problems that plague much of the world.

Indiana Journal of Global Legal Studies Vol. 22 \#2 (Summer 2015) (c) Indiana University Maurer School of Law 


\section{INTRODUCTION}

Constitutional design has only recently emerged as a legal discipline. ${ }^{1}$ This growing field of scholarship applies comparative, empirical, and cultural frameworks to consider issues related to drafting and reforming constitutions. A developed legal discipline of constitutional design-considering, for example, the process of drafting, the interaction between structural elements, and the inclusion of individual and group rights-offers valuable and practical tools for those who find themselves drafting or reforming a constitution, or advising the process. By necessity, these leaders of reform processes, and sometimes the nation as a whole, must consider a multitude of legal constitutional theories and their application. This is no easy feat. Consultants and advisers, no matter how steeped in local legal traditions, often do not have the technical legal skills or knowledge necessary to consider the vast array of constitutional mechanisms available, let alone the ways in which these mechanisms interact and form a comprehensive basis for a new system of governance. Often finding themselves perplexed and unable to find the necessary scholarship available, leaders will call upon foreign scholars and consultants to advise them throughout the drafting process.

These foreign advisers and aspects of law, much like a traded commodity, can easily travel in the globalized world. ${ }^{2}$ The free exchange

1. Cf. Maxwell O. Chibundu, Law in Development: On Tapping, Gourding and Serving Palm-Wine, 29 CASE W. RES. J. INT'L L. 167, 171 (1997) (exploring the waxing and waning of the law and development movement). Constitutional design likely sprouts as a sub-field of the recent revival of the law and development movement. Reaching its apogee in the 1970s, this movement touted the importance of law and legal institutions in the economic and social development of newly emerging and modernizing states. Id. at 169 .

2. See Toby S. Goldbach, Benjamin Brake \& Peter J. Katzenstein, The Movement of U.S. Criminal and Administrative Law: Processes of Transplanting and Translating, 20 IND. J. GLOBAL LEGAL STUD. 141 (2013) (analyzing the spread of U.S. domestic criminal and administrative law into foreign domestic and international legal spheres). "The new normal is broad consultation of a range of international models and a facility for translating multiple or even conflicting legal practices. This presents opportunities for positive legal change and complicates efforts to locate clear sources of power in the movement of law." Id. at 142. The spread of constitutional ideas may even be contagionlike. David S. Law, Globalization and the Future of Constitutional Rights, 102 NW. U. L. REV. 1277, 1286-87 (2008) (observing the international spread of women's rights and democratic norms as contagious). The globalization of these ideas is driven by many factors, including a desire to achieve and exploit positive reputations for constitutional protections of rights. Id. at 1288; see also Martin Shapiro, The Globalization of Law, 1 IND. J. GLOBAL LEGAL STUD. 37 (1993) (concluding that while there are certain globalizing trends in various fields of law, domestic legal regimes are more responsive to global changes in markets and politics rather than law). For example, "the recent worldwide preoccupation with new written constitutions dividing government powers and 
of legal ideas and knowledge of constitutional mechanisms and structures is necessary for the development of constitutional design, but the globalization of such a young field could prove dangerous if its professionals forget the contextual level in which they must ply their trade. While there are arguably some principles that are universal, the design and the content of a constitution must be completely informed by local tradition, culture, politics, and history if legitimacy is to be successfully conferred. ${ }^{3}$ Therefore, constitutional designers must never haphazardly grab and apply "best practice" provisions from a global constitutional menu; ${ }^{4}$ if they do so, they court disastrous effects. ${ }^{5}$ On the other hand, successful advising requires a freshly global and comparative perspective on available constitutional mechanisms, their theoretical underpinnings, and effective application. The dichotomy of these needs-for the concurrent globalization and localization of technical legal design and application-causes innumerable difficulties for practitioners. "Guides for the perplexed" are needed to provide

guaranteeing individual rights, the spread of constitutional courts and constitutional judicial review, and the fervor and effectiveness of the human rights movement" demonstrate a globalized declining public approval of government institutions. $I d$, at 48 . Yet, it is important to note that the studies of these trends must depend as much on the differences as the similarities among peoples, signifying the concomitant trends of globalization and localization. See id. at 64 .

3. See, e.g., Ruth Gordon, Growing Constitutions, 1 U. PA. J. Const. L. 528, 530 (1999) (proposing the idea of "growing constitutions"-constitutions can only succeed "if they are firmly planted in the cultural soil from which they gain legitimacy").

4. Consultants and advisers from intergovernmental organizations, foreign embassies, foreign universities, and nonprofit organizations clamor to advise and influence nations undergoing constitutional review or constitutional creation processes. These constitutional designers are altruistic in purpose, but often arrive with only a rudimentary idea of the country's systems, cultures, and history; additionally, they are not aware of the key stakeholders and power players. Undoubtedly, without a relationship with the key players and a thorough understanding of the country, a constitutional designer will be ineffective at designing a successful constitution. A successful constitution is not drafted with the help of a consultant who flies in for a lecture or conference and then returns home; instead, an effective constitutional designer must earn the trust of key stakeholders and understand the context of the nation's social problems and systemsthis requires years of relationship-building. To achieve both aspirational and governmental structuring goals, a constitution should be highly contextual, and designers and the design process should focus upon the social problems on the ground. See Chibundu, supra note 1, at 171 ("[T]he relevance of law for development must be grounded in the experiences of the society under study and in ways giving form and meaning to those experiences by their institutionalization, not through internationalizing the societies, nor through a universalist or global conception of procedural mechanisms or substantive rights and duties.").

5. See Gordon, supra note 3, at 542-49, for a review of the postcolonial political order in Africa after constitutions accepting colonizer values were adopted, without an understanding of the values of tribal and local peoples. 
practical and applicable information on the technical legal issues of constitutional drafting and reform. ${ }^{6}$

In order to fill a gap in the constitutional design literature and provide practitioners with a basis for more practical reports, this article will explore one structural mechanism meant to balance power within federal systems. ${ }^{7}$ What I have termed "primacy clauses" are, simply put, constitutional provisions created to resolve conflicts between national and provincial legislation. ${ }^{8}$ The most well-known example may be the Supremacy Clause of the United States Constitution; however, the U.S. approach (where federal law preempts conflicting state law) should not be mistaken as the only method to solve legislative conflict in federal systems. In an attempt to provide a tool for constitutional designers, but even more so to catalyze a thorough examination of this important balancing provision, I examined and classified the primacy clauses of all current federal nations' constitutions. This typology will inform the discussion on federal structuring in developing democracies, which is directly affected by the difficulties of concurrent globalization and localization trends in constitutional design and development.

In the developing world, the balance of power can become an "urgent political and constitutional issue" that is determinative of whether rule of law is possible. ${ }^{9}$ The balance created by the initial, constitutionally enshrined division of power is not static, and a primacy clause must

6. Scholarly literature must address the relevant issues of constitutional design from the starting point of real world problems. From there, reports can provide the options, which can then be explored and contextualized by practitioners based on the issues at hand. A successful constitutional adviser will both provide information (i.e., a menu system of options that includes the motivating reasons behind choices of design and the implications of those choices) and facilitate the application of that information in an organic and non-imposing manner. E-mail from Jason Gluck, Senior Program Officer, United States Institute of Peace to Brady Harman (Jan. 12, 2015, 17:00 EST) (on file with author).

7. Globalization has sparked a renewed interest in federalism. Populaces are increasingly interested in being both global consumers and local citizens at the same time. The strengthening of both international and local pressures has weakened the traditional, centralized nation-state in favor of more decentralized approaches to power sharing. See Ronald L. Watts, Contemporary Views on Federalism, in Evaluating Federal Systems 1, 5 (Bertus De Villiers ed., 1994). A trend toward and difficulties with decentralization can easily be seen contemporarily through the number of recent and ongoing attempts at secession (e.g., Scotland, Catalan).

8. See infra Part I for an explanation of terminology. Surprisingly, there is currently no common language within legal literature for constitutional provision(s) that resolve conflict between national and provincial legislation. "Primacy clause" shall hopefully serve as a seminal common identifier for these types of constitutional mechanisms that maintain power balances within federal systems.

9. Stephen A. Gardbaum, The Nature of Preemption, 79 CoRNELL L. REV. 767, 768 (1994). 
secure that balance when conflicts between laws arise, as they inevitably will. Therefore, it is imperative that designers of new or reformed constitutions understand and consider various approaches to primacy. As explored below, most primacy clauses are simplistic; they may do little to protect the balance of power and may actually exacerbate the siphoning of power to one level of government-toward the central government in most instances. However, some federal systems utilize a more complex primacy clause that may more accurately maintain a balance of power, regardless of whether that balance is static. or shifting.

Section I will develop the definition and explore the importance of primacy clauses as a mechanism of federalism. Section II will introduce a typology for the classification of primacy clauses and provide empirical evidence of their prevalence amongst current federal systems. Primacy clauses are classified by approach: national primacy, provincial primacy, and conditional primacy. Examples of each type of primacy clause will be explored within the context of their home constitutions to illustrate how each approach functions; related considerations and associated problems will also be assessed. Finally, the concluding section will preliminarily compare the types of primacy clauses and expound upon their possible relative strengths. Ideally, this article will serve as a foundational typology by which the implications of primacy approaches on the balance of power and effectiveness of federal systems may be further explored.

\section{FeDERALISM AND THE Role of THE PRIMACY ClaUSE}

Simply put, federalism is a system that organizes and distributes political power in a way that will enable the common needs of the people to be achieved while also accommodating the diversity of their circumstances and preferences. ${ }^{10}$ At the time of formation, federal constitutions divide and distribute power between the national government and provincial government-hopefully with enough foresight to forge a balance of power that meets the needs cited for choosing federalism in the first place. The relative strength of the various levels of government, and the overall stability of the system itself, is predicated upon this initial division of powers within the constitution; but maintenance of stability depends upon constitutional

10. Watts, supra note 7 , at 5-6. 
provisions that resolve any subsequent legislative conflict between levels-primacy clauses. ${ }^{11}$

\section{A. Intrinsic Conflict in Competitive and Cooperative Federal Systems}

Federal systems and their constitutive balancing mechanisms are extremely complex and vary among the approximately twenty-seven contemporary modern federal nations. ${ }^{12}$ Choosing federalism and a particular constitutional distribution of power is motivated by a variety of reasons. The chosen distribution typically reflects an extant balance of powers that is already present or is meant to actualize a balance that has eluded the country thus far. ${ }^{13}$ To understand primacy clauses and their effectiveness, one must first understand divisions of power between provincial and national government. ${ }^{14}$ Broad implications of typical power divisions are briefly discussed below, but the motivating reasons and goals behind these divisions must also be thoroughly

11. A fairly comprehensive exploration of the variances on power distribution in federal systems exists in scholarship today. See generally, e.g., A GLOBAL DIALOGUE ON FEDERALISM: DISTRIBUTION OF POWERS AND RESPONSIBILITIES IN FEDERAL COUNTRIES (Akhtar Majeed et al. eds., 2006), for a comparative discussion on power distribution as a core theme of federalism. However, when the literature considers power balancing, there is little comparative discussion of how a constitutional mechanism triggered during times of legislative conflict can affect the proliferation and implementation of initial divisions of power. A more robust examination of these relationships could be highly informative in the constitutional design process.

12. See Federalism By Country, Forum OF FEDERATIONS (Jan. 1, 2013), http://www.forumfed.org/en/federalism/federalismbycountry.php for a base list of federal countries. I have added South Sudan to and removed Spain from this list. Spain is often considered a de facto federation because of its strong autonomous communities, but it will be considered a unitary system here for ease of analysis. The constitutions of the following countries were analyzed in pursuit of this typology: Argentina, Australia, Austria, Belgium, Bosnia \& Herzegovina, Brazil, Canada, Comoros, Ethiopia, Germany, India, Iraq, Malaysia, Mexico, Micronesia, Nepal, Nigeria, Pakistan, Russia, St. Kitts \& Nevis, South Africa, South Sudan, Sudan, Switzerland, United Arab Emirates, United States, and Venezuela.

13. See Gordon, supra note 3, for a discussion of the colonial and postcolonial political orders and their effects on postcolonial constitutions.

14. The use of the term "national" (rather than "federal" or "central") and "provincial" (rather than "state," "community," or "territory") will be used throughout this article to denote the national and the main sub-national level of government, respectively. This is in an effort to avoid confusion created by the varied terminology used amongst different countries. Additionally, only levels of government with legislative power are considered here; therefore, local divisions with only administrative powers are not addressed. However, it should be noted that administrative power, especially in highly devolved systems, should not be ignored when considering power balancing during the design process. 
understood when considering the role of primacy clauses in balance maintenance.

The U.S. Constitution is representative of clear dualistic divisions of power between the state and federal government. The U.S. Constitution enumerates a few express powers of the federal government. ${ }^{15}$ Implied powers of the federal government are read as flowing from these express powers and the elastic clause of the Constitution. ${ }^{16}$ The Tenth Amendment goes on to state, "The powers not delegated to the United States by the Constitution, nor prohibited by it to the States, are reserved to the States respectively, or to the people."17 Therefore, U.S. states have residual powers that are not allotted to the federal government by the Constitution. This initial allotment of powerlimited enumerated federal power and substantial residual powers for states-creates and reflects a constitutional predilection for increasingly powerful and competitive states. ${ }^{18}$ To be successful, the division and balance of powers must rest on an "appropriate balance between cooperation and competition" between the national and provincial government. ${ }^{19}$ Whether balance is based more on cooperation or competition, conflict between levels of government will always present itself.

Many other federal systems have constitutions that contain, often more comprehensively, a set of enumerated lists that explicitly create shared responsibility: express national powers, express provincial powers, and mixed or concurrent powers that are shared between the two levels of government. The complex division of competence to include shared and supporting roles between levels of governance relates to the increasingly prevalent concept of cooperative or "marble cake" federalism. ${ }^{20}$ For example, the European Union and its member states

15. Federal powers are largely expressed within Article 1. See U.S. CoNST. art. I, $\$ 8$.

16. See generally M'Culloch v. Maryland, 17 U.S. 316 (1819) (referring to the Necessary and Proper Clause, which permits Congress to seek objectives within its enumerated powers as long as it is rationally related to the objective and not forbidden by the Constitution; Chief Justice John Marshall narrowly limits the authority of state governments and broadly construes Congress's powers).

17. U.S. CONST, amend. X.

18. Within "the vast realm that lies beyond the national government's reach," the states compete for the assets and attention of citizens. Michael S. Greve, Against Cooperative Federalism, 70 Miss. L.J. 557, 558 (2000).

19. Daniel J. Elazar, International and Comparative Federalism, 26 PS: POL. SCI. \& PoL. 190, 193 (1993).

20. "Marble-cake federalism" was likely first coined by Morton Grodzins in reference to an evolving American federalism; he suggested that, rather than symbolizing the government as a three-layer cake, a more accurate image would be a marble cake, "characterized by an inseparable mingling of differently colored ingredients...As colors are mixed in the marble cake, so functions are mixed in the American federal system." Morton 
have divided competencies into exclusive, shared, and supporting categories. ${ }^{21}$ Additionally, special categories of competence are specified for EU action within the spheres of economic and employment policy, and common foreign and security policy. ${ }^{22}$ Inevitably, this system's complex and overlapping division of power creates conflicts of law between the EU and member nations. Beyond inherent conflict caused by initial power divisions, conflict may also be motivated by a fear of cooperation as a form of coercion by a central government. ${ }^{23}$ Therefore, even within more cooperative federal systems, conflict is present and primacy clauses are essential. To prevent any eventual competence creep, there must be an attempt to define ex ante criteria for the resolution of conflicting laws. However, the interconnection of regulatory areas within cooperative systems are often so complex as to make the establishment of clear dividing lines difficult. ${ }^{24}$ Thereby, this may limit the ability of ex ante criteria, such as primacy clauses, to regulate central intervention.

Cooperative federalism and comprehensive constitutional enumerations of shared power are common beyond the European Union $^{25}$ and may reflect the decentralizing forces of globalization. The various challenges of globalization create a need for cooperation and the synchronization of policies across governmental levels. ${ }^{26}$ Even federalism in the United States, traditionally thought to rest on a strongly competitive foundation, has seen an increased role of the

Grodzins, The Federal System, in GOALS FOR AMERICANS: THE REPORT OF THE PRESIDENT'S COMMISSION ON NATIONAL GOALS 265 (1960).

21. See generally PAUl Craig \& GRÁInNe DE BúrCA, EU LaW 78-87 (5th ed. 2011) (discussing the details of exclusive competence, shared competence, and supporting action as defined by Articles 2(1), 2(2), and 2(5) of the TFEU, respectively).

22. See id. at 88-89 (discussing TFEU Articles 5 and 2(4), concerning economic, employment, and social policy, and common foreign and security policy, respectively).

23. See Elazar, supra note 19, at 194.

24. ANTONIO Estella, The EU PRINCIPLe of SubSIDIARITY AND Its CRITIQUe 113-114 (2002). Further investigation is needed to determine the intricacies of the relationship between primacy clauses and the complexities of administrative and regulatory cooperation.

25. Germany may be the most well-known example of cooperative federalism with complex divisions of responsibility between Länder and the federal government, requiring high levels of cooperation. UWE THAYSEN, THE BUNDESRAT, THE LÄNDER, AND GERMAN FEDERALISM 14 (1994). Some scholars argue that the unclear assignment of competencies has strangled economic success of the Länder and a more competitive system is necessary. See Bernhard Seliger, From the Cooperative Trap to Competition: Reform Perspectives for Fiscal Federalism in Germany 17-18 (Hanns Seidal Found., Working Paper No. 05-02, 2002), available at http://www.hss.de/fileadmin/korea/downloads/EWPS_05-02.pdf.

26. See Yishai Blank, Federalism, Subsidiarity, and the Role of Local Governments in an Age of Global Multilevel Governance, 37 FordHAM URB. L.J. 509, 530 (2009). 
federal government in state administration. ${ }^{27}$ However, no matter how cooperative, the traditionally competitive predilections of federalism hamper the harmonization of policies and signify that conflict is inherently present in multilevel collaboration. ${ }^{28}$

\section{B. Primacy Clauses and the Balance of Power}

The initial constitutional division of power sets the stage for all future conflict by determining later proclivities for cooperation and competition. ${ }^{29}$ No matter the effectiveness of this initial division, there is always cause for conflict between levels, and an effective means of conflict resolution is thereby required in all federal systems. ${ }^{30}$ Therefore, calculating the appropriate balance of national and provincial powers in federal countries requires consideration of both the enumerated division of powers and, just as importantly, the primacy clause.

By its nature, no constitution will ever be able to enumerate the division of power in enough detail to provide answers to the infinite number of problems faced by a governing structure. Written constitutions "can [only] establish the broad grooves in which a nationstate develops," and political forces, rather than constitutional text, determine what happens in those grooves. ${ }^{31}$ Beyond the desire of

27. American federalism has become more cooperative as state governments administer federal programs and the federal government funds state programs. Also, conditional preemption requires states to cede regulatory fields to the federal government if they do not administer a federal program or regulate according to federal standards. Greve, supra note 18, at 558. "Conditional preemption . . . forces the states to choose between two threats to their sovereignty: They must either accept the indignity of implementing federal regulation or acquiesce in the displacement of their authority by the federal government." Michael C. Dorf \& Charles F. Sabel, A Constitution of Democratic Experimentalism, 98 CoLUM. L. REV. 267, 425 (1998). See generally MICHAEL S. GREVE, THE UPSIDE-DOWN CONSTITUTION (2012) for a critical analysis of the decreasing competitiveness of American federalism.

28. See Blank, supra note 26 , at 530 .

29. As such, a later study may want to assess a possible correlation between initial divisions of power, the type of primacy clause found in the constitution, and the level of multilevel cooperation.

30. Additionally, while the most effective division of powers possible would substantially reduce inter-level conflict and reduce the need for a primacy clause, power distribution needs may change over time. This means that primacy clauses could also serve as an important tool for purposeful and progressive shifts in power distribution, rather than solely the maintenance of the original distribution.

31. PeTER Russell, Constitutional ODYssey 34 (3d ed. 2004) ("The great conceit of constitution-makers is to believe that the words they put in the constitution can with certainty and precision control a country's future. The great conceit of those who apply a written constitution is to believe that their interpretation captures perfectly the founders' 
expansion by a level of government, conflict results from a "lack of legal precision on the extent of the powers." 32 Even if a constitution enumerates the minutiae of powers of every level of government, there will be problems of classification. For example, if a nation allots power over the military to the national government and power over education to the provinces, a military school could be classified as a military power or an education power. So which level of government will manage the creation and administration of such a school? Whether one level of government moves to expand their competence or both levels share concurrent administration, conflict is inevitable. The legal doctrine to solve these national-provincial conflicts is prescribed within a constitutional primacy clause and interpreted by a constitutional court. $^{33}$

A primacy clause is a usually simple constitutional provision that determines the "winner" when there is a conflict between national and provincial legislation. As explored below, the most common primacy clause results in absolute national primacy. For example, the Australian Constitution states, "When a law of a State is inconsistent with a law of the Commonwealth, the latter shall prevail, and the former shall, to the extent of the inconsistency, be invalid." 34 The U.S. Constitution's Supremacy Clause is another example of a national primacy clause. It is extremely rare to see a primacy clause doing the opposite and preempting national legislation in favor of provincial legislation. Finally, more complex primacy provisions that provide for conditional primacy also exist. Unlike the more common absolutist approaches, conditional primacy clauses enumerate conditions, criteria, or processes to determine a "winner" dependent upon the situation.

I have chosen to name this genre of constitutional provisions as "primacy" rather than "supremacy" clauses for two reasons. First, I wish to avoid confusion with the U.S. Supremacy Clause. Although the Supremacy Clause is indeed a founding example of one primacy clause approach, it is not representative of the clauses used in all countries. Second, "primacy" conveys a preeminence and superiority without the

intentions. Those who write constitutions are rarely single-minded in their long-term aspirations. They harbor conflicting hopes and fears about the constitution's evolution.").

32. Hugues Dumont et al., Kingdom of Belgium, in 2 A GloBal DIALOGUE ON FEDERALISM: DISTRIBUTION OF POWERS AND RESPONSIBILITIES IN FEDERAL COUNTRIES 34, 56 (Akhtar Majeed et al. eds., 2006).

33. It should be noted that political landscape often predetermines the method of conflict resolution. For example, if there are symmetrical coalition governments across levels, cooperative agreements are more likely to be used, rather than the legal invocation of primacy clauses, which would result in a more adversarial litigation process of conflict resolution. Id.

34. Australian Constitution s 109. 
sense of finality inherent in the term "supremacy." 35 Therefore, "primacy" is more inclusive of the conditional approach, which does not call for the outright dominance of one level found in the other two absolutist approaches.

Primacy clauses are an extremely important yet understudied mechanism in federalism, as they are possibly predictive of the longterm balance of power between national and provincial governments. Conflict is unavoidable in a federal system; ${ }^{36}$ therefore, the method of conflict resolution serves as a bellwether of the direction in which power will likely be siphoned over time. For example, I hypothesize that a strong national primacy clause inevitably correlates with a national government that is accorded more power over time. Under this type of primacy clause, whenever there is some semblance of a relationship to an explicit or implicit national power and a conflict between levels arises, provincial law will be preempted. This a priori predilection for national governments will enable the expansion of national power to the extent that it encroaches upon and even subsumes enumerated or residual provincial power. ${ }^{37}$

Countries choose, create, and develop federal systems to strike different balances of power for different reasons. For example, the balance needed may be between varied populations to prevent ethnic conflict, thereby requiring the creation of a thin layer of culture that binds a heterogeneous people together into one nation. ${ }^{38}$ In this case, if a national primacy clause haphazardly enables power to siphon toward a national government controlled by an oppressive majority ethnic

35. The dictionary defines "primacy" as "the state of being most important or strongest." Primacy Definition, MERRIAM-WEBSTER, http://www.merriam-webster.com/ dictionary/primacy (last visited Mar. 21, 2015). "Supremacy" is defined as "the quality or state of having more power, authority, or status than anyone else: the state of being supreme." Supremacy Definition, MERRLAM-WEBSTER, http://www.merriam-webster.com/ dictionary/supremacy (last visited Mar. 21, 2015).

36. Watts, supra note 7 , at $\mathbf{1 5}$.

37. This may be especially troublesome in a globalized world where legislative centralization is common, even whilst administrative decentralization continues. For example, "[a]fter a strongly federative phase in the 1950 s a creeping centralization has occurred as a result of the [German] federal government's almost exclusive use of its concurrent legislative jurisdiction, to the point where Germany is now described as a unitary type of federalism." Hans-Peter Schneider, The Federal Republic of Germany, in 2 A Global DIALOGUe ON FEDERALISM: DISTRIBUTION OF POWERS AND RESPONSIBILITIES IN FEDERAL CoUNTRIES 124, 127 (Akhtar Majeed et al. eds., 2006).

38. Constitutional structural techniques can be utilized to reduce ethnic conflict. See DONALD L. HOROWITZ, ETHNIC GROUPS IN CONFLICT 601 (2000). "Thin culture" here signifies an expression of common values that is thin enough to not conflict with the varied cultures of a multiethnic country, but which is enough to hold that country together. Constitutional structure can induce this binding element by creating common legal rights, core values, and institutional participation. 
group, a slippery slope toward cultural dominance precludes federalism from achieving its goal of balanced governance and the protection of non-dominant or local cultures. On the other hand, if a provincial primacy clause is present and enables the siphoning of power to the provincial governments, there is a threat of ineffective central common governance. This could result in a slippery slope toward secession and the end of the nation-state.

Beyond cultural difference, there are many additional reasons for federal devolution of power: the provincial government may act more speedily than the national government when addressing certain issues; the local government would be more effective in some areas because of local knowledge (e.g., a crumbling bridge needs repair); the provinces may need to check a powerful, disconnected, and far-away national government; provincial government involves more people and more adequately fulfills principles of democracy; or the national government may be indifferent or even hostile because of identity issues. The contemporary context of social problems, history, political and economic institutions, culture, and many other factors will motivate a decision to create a system of federalism and determine the balance of power between the national and provincial governments; there is no perfect balance, only a successful balance for a specific country at a specific time.

Mindful of the need for more thorough study, I only hazard to suggest that when considering primacy clauses, constitution drafters should sacrifice some clarity in favor of effectiveness. A division of powers between multiple levels of government is created for complex and politically motivated reasons; therefore, the maintenance of that division-assuming that maintenance is preferable-will also require a tailored and flexible approach. Powers are devolved to provinces for radically variable reasons. The maintenance of the power balance would require similar consideration of these contextual factors when determining primacy.

Primacy clauses are understudied and underappreciated. Although simplicity is typical, primacy provisions that are overly absolute may disturb the balance of power through unintentional siphoning, thereby directly contributing to a drift of power that results in the demise of a federal system. Contrarily, conditional primacy clauses may effectively stabilize the initial balance of power or even act as a mechanism by which ineffective ex ante divisions of power are corrected or realigned. Either way, primacy clauses should be a centerpiece in scholarship on federalism and divisions of power. Even more importantly, constitution drafters and constitutional designers must consider primacy clauses and their long-term effects on federal structures. 


\section{A Typology of PRIMACy ClaUSes}

As they have not yet been classified as such, nor explored in a comparative sense, a typology of the various iterations of constitutional primacy clauses found in modern federal systems is needed. By studying the current constitutions of twenty-seven federal nations, ${ }^{39}$ primacy clauses have been placed into three categories based on how they resolve conflict between national and provincial law: the national primacy approach, the provincial primacy approach, and the conditional primacy approach. ${ }^{40}$ Each approach will be explored below by analyzing the express provisions of a few sample nations' constitutions. While some of the relative strengths and weaknesses of each approach can be ascertained from analysis of the express provisions, additional study is needed to examine the clauses within the nexus of other provisions that affect the balance of power.

\section{A. National Primacy Approach}

The national primacy approach is by far the most common type of primacy clause found in the constitutions of modern federal nations. Of the nineteen federal countries with explicit primacy clauses, fifteen of them fall within this approach. The United States and Australia will be explored below as exemplars of this approach. Other countries that follow this approach include Bosnia and Herzegovina (art. III 3(b)), Brazil (art. 24(4)), Canada, Comoros (art. 8), Germany (art. 31), Malaysia (art. 75), Mexico (art. 133), Nigeria (art. 4(5)), Russia (art.

39. The web-based Constitute Project was utilized to examine the relevant constitutions in English. The following countries' constitutions were examined: Argentina, Australia, Austria, Belgium, Bosnia \& Herzegovina, Brazil, Canada, Comoros, Ethiopia, Germany, India, Iraq, Malaysia, Mexico, Micronesia, Nepal, Nigeria, Pakistan, Russia, St. Kitts \& Nevis, South Africa, South Sudan, Sudan, Switzerland, United Arab Emirates, United States, and Venezuela. Explore Constitutions, CoNSTITUTE, https:/www. constituteproject.org (last visited Jan. 15, 2015).

40. Constitutions of eight federal systems do not fit within this typology. The constitutions of five nations (Argentina, Ethiopia, Micronesia, Nepal, and Venezuela) do not make any explicit reference to resolving conflict between national and provincial law. The constitutions of Austria and the United Arab Emirates empower the Constitutional Court and Federal Supreme Court, respectively, to resolve conflicts of competence, but do not provide any explicit guidance to the Court. See BUNDES-VERFASSUNGSGESETZ [B-VG] [CoNSTITUTION] BGBI No. 1/1930, art. 138 (Austria); THE CONSTITUTION OF THE UNITED ARAB EMIRATES [1971] art. 99(2). The constitution of Belgium leaves the question of conflict resolution methodology to be determined by federal law. 2012 CoNST. art. 141 (Belg.). 
76(5)), St. Kitts \& Nevis (art. 103(2)), South Sudan (Transitional Constitution, Schedule E), and Switzerland (art. 49).41

Australia demonstrates the simplicity typical of national primacy clauses. Just one sentence ensures that national law preempts any conflicting provincial law. Section 109 of the Australian Constitution states, "When a law of a State is inconsistent with a law of the Commonwealth, the latter shall prevail, and the former shall, to the extent of the inconsistency, be invalid." 42

For purposes of Section 109, inconsistency arises:

(i) where simultaneous obedience to the law of the Commonwealth and to the law of the State is impossible; (ii) where the law of the State takes away or varies a right, privilege, duty, power or immunity conferred by a law of the Commonwealth (or, conversely, a law of the Commonwealth takes away or varies a right, privilege, duty, power or immunity conferred by law of the State); or (iii) where the law of a State invades a field which the law of the Commonwealth was intended to cover exhaustively. ${ }^{43}$

The presence of inconsistency, per the factors above, attracts the operation of Section 109 to invalidate conflicting state law, but invalidity is not produced directly. ${ }^{44}$ Section 109 only operates on state law that has already been lawfully enacted; it does not support national

41. Constitution of Bosnia and Herzegovina (art. III 3(b)); ConstituIÇÃo FEDERAL [C.F.][Constitution] art. 24, para. 4 (Braz.); Comoros Constitution (art. 8); GRUNDGESETZ FÜR DIE BUNDESREPUBLIK DEUTSCHLAND [GRUNDGESETZ][GG][BASIC LAW], May 23, 1949, BGBl. I at art. 31 (Ger.); Constitution of Malaysia (art. 75); Constitución Política de los Estados Unidos Mexicanos [C.P.], as amended 2007, art. 133, Diario Oficial de la Federación [DO], 5 de Febrero de 1917 (Mex.); CONSTITUTION OF NigERIA (1999), § 4(5); Konstitutsila RossisskoI FEDERATSII [KONST. RF][CONSTITUTION] art. 76, $§ 5$ (Russ.); St. Kitts \& Nevis Constitution, 1983 (art. 103(2)); Transitional Constitution of the Republic of South Sudan, 2011 (Schedule E); BUNDESVERFASSUNG [BV][CONSTITUTION] Apr. 18, 1999, SR 101, art. 49 (Switz.). "Section 90 [of the Canadian Constitution] gives the federal government the unilateral power to 'disallow' (invalidate) any provincial legislation" through the provisions found in Section 56. Richard Simeon \& Martin Papillon, Canada, in 2 A Global Dlalogue on Federalism: Distribution of Powers AND RESPONSIBILITIES IN FEDERAL COUNTRIES 91, 99 (Akhtar Majeed et al. eds., 2006). Section 92A(3) contains a more traditional national primacy clause but only relates directly to non-renewable natural resources, forestry resources, and electrical energy. Constitution Act, 1982, being Schedule B to the Canada Act, 1982, c. 11, art. 92A(3) (U.K.).

42. AUSTRALIAN CONSTITUTION S 109.

43. Felman v Law Inst. (Vic) (1997) 142 FLR 362 (Austl.).

44. Id. (citing W. Austl. v Commonwealth (1995) 183 CLR 373, 464-65 (Austl.)). 
laws that purport to prohibit state parliament lawmaking ex ante. ${ }^{45}$ Much like the United States, the initial distribution of enumerated constitutional powers to the Commonwealth and residual powers to the states means that inconsistency (i.e., conflict) between legislative provisions governing the same matter is inevitable. Section 109, the national primacy clause, prescribes which law shall prevail, but consistent with most primacy approaches of this type, the invalidation (i.e., preemption) of provincial law does not encompass the entirety of the affected legislation. ${ }^{46}$ In Australia, and most other federal systems, "[s]tate law remains valid though it is rendered inoperative to the extent of the inconsistency, but only for so long as the inconsistency remains." 47

The Supremacy Clause of the U.S. Constitution is likely the most influential primacy clause used by a competitive federal system, ${ }^{48}$ but the complexity of its concepts makes it unique. Article VI, Section 2 of the U.S. Constitution reads,

This Constitution, and the Laws of the United States which shall be made in Pursuance thereof; and all Treaties made, or which shall be made, under the Authority of the United States, shall be the supreme Law of the Land; and the Judges in every state shall be bound thereby, any Thing in the Constitution or Laws of any state to the Contrary notwithstanding. ${ }^{49}$

45. See Gerhardy v Brown (1985) 159 CLR 70, 121 (Austl.).

46. Most constitutions with national primacy clauses explicitly state that provincial law is only preempted to the extent of the inconsistency. For example, the primacy clauses of Pakistan ("the Act of the Provincial Assembly shall, to the extent of repugnancy, be void."), Canada ("the law of Parliament prevails to the extent of the conflict."), and Nigeria ("and that other Law shall, to the extent of the inconsistency, be void.") include language similar to the Australian clause. PAKISTAN CONST. art. 143; Constitution Act, 1982, being Schedule B to the Canada Act, 1982, c. 11, art. 92A(3) (U.K.); ConSTITUTION OF NIGERIA (1999), § 4(5).

47. W. Austl. v Commonwealth (1995) 183 CLR 373, 464-65 (Austl.).

48. The federal system of the United States has proven highly influential in the creation and construction of federal systems around the world. Federalism has taken on new appeal, and while it has many variations, the "bold experiment" of the U.S. Constitutional Convention has served as a model for the division of powers and thereby merits special attention for the American primacy clause, the Supremacy Clause. A.E. Dick Howard, $A$ Traveler from an Antique Land: The Modern Renaissance of Comparative Constitutionalism, 50 VA. J. INT'L L. 3, 25-26 (2009).

49. U.S. ConsT, art. VI. 
Let us first simplify and then consider the elements that set the U.S. primacy clause apart from other clauses of the national primacy approach.

Article VI, Section 2 directly states that the Constitution, federal laws, and treaties take precedence and preempt any conflicting state laws or constitutions. This seems at odds with some of the founding principles of the United States. James Madison viewed "We the People" as the source of the legitimate exercise of federal power: legitimate power originates from the periphery-the states-rather than the center, as had been the common European view at the time. ${ }^{50}$ The Constitution, which defined a limited number of exclusive federal powers but assigned all residual powers to the states, reflected this viewpoint. The Founders yearned for a nation with a central government strong enough to be effective but not strong enough to usurp the role of the states. By designing the principal branches of the government to be dependent upon the states, the Founders thought the federal law-making process would inherently protect states' rights; the process would beget a system with a "disposition too obsequious [rather] than too overbearing towards" the states. ${ }^{51}$

The clause recognizes three sources of law that are the "the supreme Law of the Land": the Constitution, the laws, and the treaties of the United States. ${ }^{52}$ Uniquely, the clause only encompasses the laws of the United States that "shall be made in Pursuance" of the Constitutionthus not every federal law qualifies. ${ }^{53}$ Therefore, beyond primacy in conflict, the Supremacy Clause calls for active judicial policing of the bounds of federal power exercised by Congress, requiring a court to determine what law is supreme and "made in Pursuance" of the Constitution-what laws fall within an explicit or implicit enumerated power in the Constitution. ${ }^{54}$ The U.S. Constitution is unique in that the primacy clause itself expressly impresses the courts, including state

50. See Stephen Breyer, MaKING OUR Democracy WorK 122 (2010). But see McCulloch v. Maryland, 17 U.S. 316, 402-04 (1819) for John Marshall's famous assertions that federal authority is derived directly from the people as a whole rather than via the states.

51. The Federalist No. 45, at 291 (James Madison) (Clinton Rossiter ed., 1961).

52. Bradford R. Clark, The Supremacy Clause as a Constraint on Federal Power, 71 GEO. WASH. L. REV. 91, 99 (2003).

53. Id.

54. Id.; see Bradford R. Clark, Separation of Powers as a Safeguard of Federalism, 79 TEX. L. REV, 1321, 1348 (2001) (expounding upon the other possible methods of enforcement considered at the constitutional convention-executive force, congressional negative). 
judges, into the policing of state law and the subordination of state law to federal law. ${ }^{55}$

Whatever their original intentions, U.S. Constitution drafters did not foresee the tilting effects of expansive judicial interpretations of federal powers and the Supremacy Clause. ${ }^{56}$ They originally viewed the Supremacy Clause as necessary to ensure that the Constitution did not become a "mere treaty, dependent on the good faith of the parties, and not a government." ${ }^{57}$ Indeed, it did achieve that goal and contributed to much more.

According to some, "American federalism has [now] become an administrative, 'cooperative federalism': state and local governments administer and implement federal programs." 58 It is no secret that U.S. constitutional jurisprudence, largely via interpretation of the commerce clause and Supremacy Clause, has resulted in the extreme expansion of national power since the founding of the United States. ${ }^{59}$

The Great Depression and the resultant policies of the New Deal resulted in considerable growth of government that continued throughout the 1960 s and 1970 s with the creation of large-scale cooperative programs. ${ }^{60}$ This would not have been possible if the Supremacy Clause did not allow for the unconditional preemption of

55. See James S. Liebman \& William F. Ryan, "Some Effectual Power": The Quantity and Quality of Decisionmaking Required of Article III Courts, 98 CoLUM. L. REV. 696, 764 (1998). The police functions of the courts are supported in other constitutional provisions as well. See U.S. CONST. art. III (parallel language to the Supremacy Clause, stating that the Supreme Court shall have appellate jurisdiction in all cases "arising under this Constitution, the Laws of the united States, and Treaties made, or which shall be made, under their Authority."); U.S. CONST. amend. X. Most other national primacy clauses do not directly refer to court monitoring and enforcement of jurisdictional boundaries. Like the United States, the Mexican primacy clause would also serve as an exception in this respect. See Constitución Política de los Estados Unidos Mexicanos [C.P.], as amended, art. 133, Diario Oficial de la Federación [DO], 5 de Febrero de 1917 (Mex.).

56. See Caleb Nelson, Preemption, 86 VA. L. REV. 225, 226-28 (2000) (discussing express and field preemption); Thomas B. McAffee, The Federal System as Bill of Rights: Original Understandings, Modern Misreadings, 43 VILL. L. REV. 17, 18 (1998) (referencing Wickard's effects on preemption); see generally ERWIN CHEMERINSKY, CONSTITUTIONAL LAW 376-401 (2d ed. 2002) (providing a general background of problems associated with preemption doctrine).

57. THE FEDERALIST No. 34, at 204 (Alexander Hamilton) (Clinton Rossiter ed., 1961); see THE FEDERALIST No. 44, at 286 (James Madison) (Clinton Rossiter ed., 1961) (stating that "all of the authorities contained in the proposed Constitution, so far as they exceed those enumerated in the Confederation would have been annulled, and the new Congress would have been reduced to the same impotent condition with their predecessors").

58. Greve, supra note 18 , at 558.

59. See CHEMERINSKY, supra note 56, at 230-38 (describing the framework set in the seminal case of $\mathrm{McCulloch} v$. Maryland, which defines the scope of federal legislative power expansively and limits the ability for states to interfere).

60. See Greve, supra note 18 , at 577 . 
state laws that conflicted with national law. A slew of cases, decided in the early twentieth century, expanded the powers of the federal government and broadened the amount of state law that would be in conflict and thereby preempted.61 Until recently, there had been no holdings by the Supreme Court to reverse this trend by limiting federal power. ${ }^{62}$ The issue is further complicated by the Tenth Amendment, where the Supreme Court has vacillated between interpretive approaches-one that protects a zone of exclusive control for the states and one that does not. ${ }^{63}$ The Supremacy Clause has not only been unable to stop the siphoning of power toward the federal government and the resultant tilting of the balance of powers, but it may also have actually enabled the process through absolute preemption of conflicting state law. ${ }^{64}$

There have been suggested reforms to reduce conflict preemption, including "finding a conflict between state and federal law only if it is physically impossible to comply with both-a proposal that would dramatically reduce the preemptive scope of federal statutes."65 However, because the reform would likely lack the permanency of a constitutional amendment, a later court could easily undo this "direct conflict" doctrine. Alternatively, some argue that subsidiarity principles could have a place in U.S. law, ${ }^{66}$ but the concomitant doctrine of harmonization does not fit within the meaning of the non obstante wording of the U.S. Supremacy Clause--the last provision of the clause

61. See generally, e.g., NLRB v. Jones \& Laughlin Steel Corp., 301 U.S. 1 (1937); see also United States v. Darby, 312 U.S. 100 (1941); Wickard v. Filburn, 317 U.S. 111 (1942).

62. In United States v. Lopez, 514 U.S. 549 (1995), the Court invalidates a federal law for exceeding the scope of the Commerce Clause for the first time in decades.

63. See CHEMERINSKY, supra note 56, at 304-05.

64. See McAffee, supra note 56, at 18-19 (stating that Framers were wrong to assume that the limited grant of authority would be sufficient means to secure a wide range of rights in our system of fundamental law).

65. Nelson, supra note 56, at 231. Some argue that within politicized federalism environments direct conflict doctrine could result in mechanical over-regulation, but within the context of Canadian constitutional law, the test has proven to be successfully protective of provincial law. Victoria Bronstein, Conflicts, in CoNSTITUTIONAL LAW OF SouTH AFRICA 16-5 to -9 (Stuart Woolman \& Michael Bishop eds., 2d ed. 2014).

66. "Subsidiarity insists that governmental power to deal with a particular kind of problem should rest in the hands of the smallest unit of government capable of dealing successfully with that kind of problem." BREYER, supra note 50, at 123; see id. at 123-25, 132-33 (explaining the basics of the subsidiarity principle, how the concept prefers decentralization, and what role it may play in preemption); see also George A. Bermann, Taking Subsidiarity Seriously: Federalism in the European Community and the United States, 94 COLUM. L. REV. 332 (1994) (exploring the role of subsidiarity in the United States). 
"rejects a general presumption that federal law does not contradict state law."67

It would be reasonable to hypothesize that those countries following the national primacy approach will discover a predilection for upward power-siphoning, similar to the United States. However, a primacy clause is only one factor amongst a constellation of constitutional and extra-constitutional factors that may tip the original balance of powers. 68 Although possibly abated by a division of powers favoring provincial law, ${ }^{69}$ a national supremacy approach for conflict resolution seemingly results, ceteris paribus, in the eventual tilting of the balance of powers toward the central government.

\section{B. Provincial Primacy Approach}

The provincial primacy approach is the diametrically opposed absolutist approach to conflict resolution, with results oppositional to those of the national primacy approach. This constitutional approach for primacy clauses allows for the primacy of provincial or regional law when it is in conflict with national legislation. Predictably, this is an extremely rare method for federal constitutions to employ. Of the nineteen federalist countries with explicit primacy clauses, only one

67. Nelson, supra note 56 , at 293 ; see id. at 292-98 (providing a textual analysis of the "non obstante" language in the U.S. Supremacy Clause).

68. Further study of judicial application of the national primacy clause, the initial constitutional distribution of powers, and relevant political and economic circumstances is required to fully understand the effects of a particular clause within wider nexus of its home constitution and national system. For example:

Despite its original rigidity, the division of powers in Canada turned out to be highly permissive. ... Its original, highly centralized division of powers has evolved - through judicial interpretation and political developments - into a much more decentralized arrangement. The limited asymmetry set out in the Constitution has also evolved into a high degree of functional asymmetry. ... [A]djustments have been the result of intergovernmental bargaining and informal agreements. The result is neither clear nor coherent, but it is workable.

Simeon \& Papillon, supra note 41, at 115 .

69. An original division of powers, a constitutional context, and a culture that values decentralization of power will counteract the centralizing tendencies of a strong national primacy clause. For example, despite the presence of a national primacy clause, the Swiss Confederacy's commitment to general principles of direct democracy and a bottom-up approach to dividing powers between the different levels of government seem to have counteracted any resultant predilections for centralization. Switzerland's flexible federalism has enabled political contest to strike the right equilibrium between the functional requirements of a modern state and its federalist commitments. Thomas Fleiner, Swiss Confederation, in 2 A Global DIALOGUe on FEDERALISM: Distribution of POWERS AND RESPONSIBILITIES IN FEDERAL COUNTRIES 266, 286-87 (Akhtar Majeed et al. eds., 2006). 
follows this approach. Iraq's primacy clause provisions are found under both the section delineating powers of the federal government and powers of the regions, Articles 115 and 121(second), respectively:

115. All powers not stipulated in the exclusive powers of the federal government belong to the authorities of the regions and governorates that are not organized in a region. With regard to other powers shared between the federal government and the regional government, priority shall be given to the law of the regions and governorates not organized in a region in case of dispute. ${ }^{70}$

121 (Second). In case of a contradiction between regional and national legislation in respect to a matter outside the exclusive authorities of the federal government, the regional power shall have the right to amend the application of the national legislation within that region. ${ }^{71}$

In the case of dispute between legislation concerning the shared powers of the federal government and the regional or governorate (provincial) governments, courts will generally give priority to the regional or governate legislation. ${ }^{72}$

Considering that there are only nine powers listed as exclusively belonging to the federal government and "the allocation of power in pivotal areas remains vague,"73 this could be an extremely influential

70. Article 115, Doustour Joumhouriat al-Iraq [The Constitution of the Republic of Iraq] of 2005.

71. Article 121(Second), Section 5, Doustour Joumhouriat al-Iraq [The Constitution of the Republic of Iraq] of 2005. Note that whilst Article 115 applies to regions, provinces, and governorates, Article 121 only applies to regions.

72. The Kurds have gone so far as to interpret the framework of Article 121 to mean that "any federal law, because it necessarily changes the effective law in the region existing up to the point of the federal law's enactment, contradicts or conflicts with a law that is in effect in the region and therefore does not stand unless the region chooses to adopt it." Haidar Ala Hamoudi, Negotiating IN Civil Conflict: Constitutional CONSTRUCTION AND IMPERFECT BARGAINING IN IRAQ 159 (2013).

73. Nicole B. Herther-Spiro, Comment, Can Ethnic Federalism Prevent 'Recourse to Rebellion?" A Comparative Analysis of the Ethiopian and Iraqi Constitutional Structures, 21 EMORY INT'L L. REV. 321, 341 (2007); Article 110, Section 4, Doustour Joumhouriat alIraq [The Constitution of the Republic of Iraq] of 2005. The Kurds were extremely successful in negotiating the shift of exclusive authority in earlier drafts to the list of concurrent powers. Michael J. Kelly, The Kurdish Regional Constitution Within the Framework of the Iraqi Federal Constitution: A Struggle for Sovereignty, Oil, Ethnic 
and powerful primacy clause. Most of the nine federal powers are unthreatening basic regulatory powers that ensure ease of uniformity across regions (e.g., regulation of standards of measurement, broadcast frequencies, and mail). ${ }^{74}$ Per Article 114, shared powers include health policy, educational policy, development planning, and energy regulation ${ }^{75}$ - powers that could be extremely dangerous if they were to be siphoned to an autocratic central regime via a national primacy approach to conflict resolution. Outside of these limited areas, powers are exclusively regional, meaning the provinces of Iraq have, ceteris paribus, unprecedented power under the new Iraqi federal constitution. ${ }^{76}$

Once again, the determination of whether there is a conflict of legislation is the threshold issue; as in the national primacy approach, a determination of conflict, resting upon the initial division of powers and the contemporary judicial approach to its interpretation, will create an unconditional preemption of conflicting law. ${ }^{77}$ However, complexities arise; for example, control of oil and gas do not fall within the lists of exclusive or shared authority, but rather in their own separate, somewhat vague constitutional provisions..$^{78}$ By choosing to consider oil and gas separately from the regular list of shared powers, the drafters did not likely intend regional or governorate law to automatically trump federal legislation via the primacy clauses; ${ }^{79}$ instead, the judiciary must create a separate test to determine the resolution of conflicts concerning these resources.

As may be intuited, the provincial primacy approach would likely result in a predilection opposite of any trends created by the national primacy approach. A fully realized provincial primacy clause may dangerously flirt with decentralization to the extent that secession or fragmentation could occur. Citing Article 115 and Article 121, which

Identity, and the Prospects for a Reverse Supremacy Clause, 114 PENN ST. L. REv. 707, 754-55 (2010).

74. See Article 110, Section 4, Doustour Joumhouriat al-Iraq [The Constitution of the Republic of Iraq] of 2005.

75. Article 114, Section 4, Doustour Joumhouriat al-Iraq [The Constitution of the Republic of Iraql of 2005.

76. Herther-Spiro, supra note 73, at 350. Although Article 122(2) may be used to circumscribe provincial power by allowing the national government to define the extent of federal power more precisely via subsequent legislation. See HAMOUDI, supra note 72 , at $166-67$.

77. Unfortunately, Iraq is currently a poor laboratory for study of the application of the Article 115 primacy clause as a substantial body of judicial interpretation has not yet been formed. See Kelly, supra note 73, at 729.

78. See Article 111-12, Section 4, Doustour Joumhouriat al-Iraq [The Constitution of the Republic of Iraq] of 2005.

79. See Kelly, supra note 73 , at 756. 
enumerates regional powers, critics of Iraqi federalism worry that regional legislation could supersede the Iraqi Constitution and thereby unilaterally render the central government ineffective. ${ }^{80}$ Fragmentation is an inherent danger to highly decentralized federal states, but mechanisms can be put into place to ensure foundational national cohesion. For example, the Iraqi Constitution provides for Constitutional supremacy, despite the presence of a strong provincial primacy clause. ${ }^{81} \mathrm{~A}$ preference for decentralization in situations of conflicting law is not dispositive of a successful federal central government.

There is no evidence of another contemporary federal constitution that utilizes a primacy clause following the approach of provincial primacy. While there is assuredly variation in the level of decentralization afforded in federal constitutions, even some of the most decentralized systems do not seem to employ a provincial primacy approach to conflict resolution. For example, Switzerland, often considered one of the most devolved federal systems, employs a fairly standard national primacy clause. ${ }^{82}$ But perhaps this is to be expected, as a system so decentralized may be in need of some type of centralizing mechanism to ensure stability in times of conflict. Only time and the development of Iraqi jurisprudence will determine the success of their decentralizing provincial primacy approach to conflict resolution.

\section{Conditional Primacy Approach}

Unlike the previous two approaches, the final approach to primacy is not absolutist in nature. A conditional primacy clause is a moderate answer to legislative conflict that lies somewhere on the spectrum between national and provincial primacy; it does not promise that national or provincial legislation "wins" outright whenever it is established that a conflict is present. Instead, the constitution explicitly enumerates sets of conditions to direct the process of determining whether provincial or national law has primacy in that particular situation. To render an approach flexible enough to address the

80. See Saad Naji Jawad \& Sawsan Ismail al-Assaf, Iraqi Federalism: Empowering the Governorates at the Expense of the State, ALJAZEERA CENTER FOR STUDIES 3-4 (June 27, 2012), http://studies.aljazeera.net/ResourceGallery/media/Documents/2012/6/27/20126277 2047220734Iraqi\%20federalism.pdf.

81. Article 13,121, Doustour Joumhouriat al-Iraq [The Constitution of the Republic of Iraq] of 2005.

82. See BUndesverfassung [BV] [Constitution] Apr. 18, 1999, SR 101, art. 49, para. 1 (Switz.) (stating that: "Federal law takes precedence over any conflicting provision of cantonal law."). 
multitude of areas in which conflict may arise, a certain amount of detail and complexity is typically required. Finally, conditional approaches vary widely among the nations utilizing these primacy clauses: Is the conflict resolution dependent upon conditions of subject matter, conditions of effectiveness, or conditions of approval by other branches?

Three of the nineteen nations with explicit primacy provisions follow a conditional approach. South Africa, Sudan, and India enumerate conditional criteria to determine national or provincial primacy in cases of conflict, but in radically different ways. South Africa lists complex and detailed subject-matter conditions to determine primacy, while Sudan's primacy clause demands an analysis of the effectiveness of the relevant laws, based on aspirational goals. Finally, the primacy clause of India provides for the primacy of provincial legislation when the assent of the President is assured. Already, one can see that conditional primacy clauses are radically variable and highly contextual.

\section{South Africa}

First, let us turn to South Africa. The South African Constitution allots a sizeable portion of its text to resolve conflicts of law. ${ }^{83}$ These provisions lay out, in detail, the process, criteria, and bodies that are part of the conflict resolution process. First, Section 150 explicitly states a preference for legislative interpretation that "avoids a conflict, over any alternative interpretation that results in a conflict." 84 This explicit attempt to avoid conflicting law could be reflective of the focus on harmony, compromise, and reconciliation that was common in the politics of 1990 s South Africa. ${ }^{85}$ This provision seems to signify that courts would rarely utilize the primacy clause, but succeeding judicial decisions have refused to avoid conflict via interpretative means. ${ }^{86}$

If a "conflict between national legislation and provincial legislation falling within a functional area listed in Schedule 4" (the concurrent powers list) is established, courts must engage in the calculus of Section $146 .{ }^{87}$ Section 146(5) states that provincial legislation prevails over

83. S. AFr. CoNST., 1996, $§ ~ 146-50$.

84. S. AFR. CONST., 1996, $\$ 150$.

85. Bronstein, supra note 65 , at $16-4$ to -5 .

86. See 1 Iain CurRie, Johan de WaAl, PierRe de Vos, Karthy Govender \& Heinz Klug, The New Constitutional \& Administrative LaW 221-22 \& n. 470 (Iain Currie \& Johan De Waal eds., 2001). Although a literal interpretation of Section 150 may seem to call for a direct conflict approach, if this was the case Section 146 would be rendered meaningless. Article 146 anticipates that the judiciary will play an active role in the resolution of legislative conflict. Bronstein, supra note 65 , at 16-16 to -17.

87. S. AFR. CONST., 1996, § 146(1). 
national legislation, as long as the conditions enumerated in Section 146(2)-(3) do not apply - otherwise the preference for provincial primacy is overridden in favor of the national legislation. ${ }^{88}$ The conditions that result in national primacy are based upon values of effectiveness, unity, and necessity. National legislation prevails over provincial legislation if:

(i) the matter cannot be regulated effectively by provincial legislation; 89

(ii) the matter requires uniformity and the national legislation establishes norms and standards, a framework, or national policies; 90

(iii) the national legislation is necessary for maintenance of national security or economic unity, the protection of the common market, cross-provincial economic activity, or equal access to the government, or the protection of the environment; 91 or

(iv) the national legislation intends to prevent unreasonable provincial action that is prejudicial to the economic, health, or security interests of other provinces or the nation, or provincial

88. S. AFR. CONST., 1996, § 146(5).

89. S. AFR. CONST., 1996, $\S 146(2)(a)$. Uniformity should not be advanced for the sake of uniformity. "It is inherent in our constitutional system, which is a balance between centralized government and federalism, that on matters in respect of which the provinces have legislative powers they can legislate separately and differently. That will necessarily mean that there is no uniformity." Bronstein, supra note 65, at $16-22$ (quoting the Constitutional Court in Mashavha v. President of the Republic of South Africa \& Others, 2005 (2) SA 476 (CC), 2004 (12) BCLR 1243 (CC) at ๆ 49 (S. Afr.)).

90. S. AFR. CONST., 1996, $§ 146(2)$ (b)(i)-(iii); see discussion supra note 89 . Also, framework legislation does not per se fulfill uniformity requirements here; the uniformity criterion is actually a significant limitation on overrides of provincial primacy. Bronstein, supra note 65, at 16-24 (citing Certification of the Amended Text of the Constitution of the Republic of South Africa, 19961997 (2) SA 97 (CC), 1997 (1) BCLR 1 (CC) at ๆ 157 (S. Afr.) [hereinafter Second Certification Judgment]).

91. S. AFR. CONST., 1996, § 146(2)(c)(i)-(vi). "Some deference to the national authority in these areas is inevitable." Bronstein, supra note 65, at 16-21 (quoting Certification of the Constitution of the Republic of South Africa 1996 (4) SA 744 (CC) at n.277 (S. Afr.) (First Certification decision). However, in the Second Certification Judgment, the Court explicitly stated that the determination of necessity is objectively justiciable without any presumption in favor of national primacy. Id. at 16-25 to 16-26 (citing Second Certification Judgment at 155). 
action that impedes implementation of national economic policy. ${ }^{92}$

While provincial primacy is the default, the wide-ranging conditions that override this presumption give the national government significant power to influence conflict outcomes. Still, the drafting process indicates that the analysis of the South African primacy clause should not regard provincial legislation lightly. Section 146 should not be discounted-it will hopefully develop a robust jurisprudence and effectively facilitate democratic accountability at the appropriate level, creating meaningful federalism. ${ }^{93}$

The National Council of Provinces (NCOP)-the upper house of the Parliament of South Africa, which is comprised of delegations from each of the nine South African provincial legislatures-also plays a significant role in conflict resolution. First, when determining the necessity of national legislation for conflict resolution purposes, the approval or rejection by the NCOP must be given "due regard."94 Second, subordinate legislation-law not made by a legislative body, typically regulations and proclamations ${ }^{95}$-at both the national and provincial level must have the approval of the NCOP to prevail when it is in conflict with legislation from another sphere. ${ }^{96}$ The prevailing legislation is automatically approved if the NCOP does not reach a decision within thirty days. ${ }^{97}$ If the NCOP does not approve, it must provide reasoning to the authority that referred the law to it.98 Significantly, when subordinate legislation is involved, the NCOP takes on a powerful oversight role that it normally does not fill. ${ }^{99}$ Because the

92. S. AFR. CoNST., 1996, $§ 146(3)$ (a)-(b). It is noteworthy that, unlike 146(2) conditions for national primacy, national legislation fulfilling the conditions in 146(3) are not required to apply uniformly with regard to the country as a whole. No case has yet determined what action by a province is unreasonable under this section. It is likely a high threshold, meant to target renegade provincial legislation. Bronstein, supra note 65 , at $16-28$.

93. Bronstein, supra note 65 , at 16-18. The two Certification Judgments significantly toned down original drafts of Article 146 that would have made it a "rubber stamp for centralism." Id.

94. S. AFr. Const., 1996, § 146(4). The Second Certification Judgment Court interprets "due regard" to signify only that consideration must be given to the NCOP decision. Bronstein, supra note 65, at 16-26 (quoting Second Certification Judgment at 9155 ).

95. Christina MuRRAY \& Lia NIJZINK, BUILDING REPRESENTATIVE DEMOCRACY: SOUTH AFRICA'S LEGISLATURES AND THE CONSTITUTION 107 (2002).

96. S. AFR. CONST., 1996, § 146(6).

97. S. AFR. CONST., 1996, § 146(7).

98. S. AFR. CONST., 1996, §146(8).

99. See MURRAY \& NIJZINK, supra note 95, at 108. "In the national Parliament, the main responsibility for overseeing subordinate legislation rests with the National 
NCOP is composed of delegations sent by the provincial legislatures, these provisions ensure the provinces as a whole, albeit via a national body, have a say in the determination of primacy. Indeed, the courts may more generally regard the position of the NCOP when resolving any conflicts of law, reflecting the South African dedication to cooperative government and the NCOP's role as the coordinator of national and provincial legislative efforts. ${ }^{100}$

The South African Constitution also creates a hierarchy of law in the event of conflicts beyond legislation. If there is a conflict between national legislation and provincial constitutional provisions, provincial constitutions are given no special status and will be dealt with in the same manner as conflicts between national and provincial legislation regarding concurrent competences. ${ }^{101}$ If a court cannot resolve a conflict by any of the above processes, then national legislation prevails. ${ }^{102}$ The court does not invalidate de jure the preempted legislation, but that legislation will be temporarily inactive as long as the prevailing legislation is in effect. ${ }^{103}$ This distinction-which is fairly common to primacy provisions, but atypically explicit here-ensures that subordinated law remains in force to the extent that it does not conflict with the prevailing law and will revive if the conflict falls away for some reason. ${ }^{104}$

The Constitution of South Africa contains, by far, the most comprehensive primacy clause. Existing case law, though exceedingly sparse, indicates that the multilayered considerations and conditions used by the Constitutional Court create a complex but workable means by which to determine primacy. It would be premature to conclude that this conditional primacy clause will perfectly maintain or adjust, as needed, the delicate balance of federalism. However, it is reasonable to intimate that conflict resolution in South Africa will more effectively maintain the balance of power than the other primacy approaches, possibly because this conditional primacy clause adheres to and invokes the very factors and values that informed the initial choice of federalism

\footnotetext{
Assembly." Id. The review of subordinate legislation typically utilizes clear standards to determine its legality and constitutionality. Id. It may be that the NCOP does not have procedures in place to implement the processes dictated by Sections 146(6-8). Id.

100. See CURRIE \& DE WAAL, supra note 86 , at 221.

101. See S. AFR. ConST., 1996, \$ 147(1); Certification of the Constitution of the Republic of South Africa 1996 (4) SA 744 (CC) at 150 para. 269 (First Certification decision).

102. S. AFR. CoNST., 1996, $\S 148$. It is currently unclear when this clause will come into play.

103. S. AFR. CONST., 1996, art. 149.

104. CURRIE \& DE WAAL, supra note 86 , at 222.
} 
and the chosen constitutional balance of power. ${ }^{105}$ Nonetheless, principles of cooperative federalism are strongly adhered to and intergovernmental dispute is only brought to the courts as a last resort; therefore, while the South African primacy clause may serve as a model approach, political bargaining will ultimately determine the future balance of power in this country. 106

\section{Sudan}

A much simpler conditional primacy clause can be found in the Sudanese Constitution and the 2005 Interim Constitution of Southern Sudan, albeit not the current Constitution of South Sudan. The Interim South Sudan Constitution mirrors Sudan's exactly in this respect, so I will refer solely to the latter's Constitution. Below the schedules of concurrent and exclusive powers, Schedule F pertains to the resolution of conflicts in respect to laws concerning concurrent powers.107 Whichever conflicting legislation deals most effectively with the subject matter, considering the following criteria, shall prevail:

(1) The need to recognize the sovereignty of the Nation while accommodating the autonomy of Southern Sudan or of the states; (2) whether there is a need for National or Southern Sudan norms and standards; (3) the principle of subsidiarity; and (4) the need to promote the welfare of the people and to protect each person's human rights and fundamental freedoms. ${ }^{108}$

Citing effectiveness, the aspirational goals listed in Schedule F steer the courts when determining primacy in Sudan. Autonomy, unity, subsidiarity, and the protection of fundamental rights motivate conflict resolution in the courts. Within this clause there is no preference for provincial or national dominance (i.e., there is no default rule here). The

105. The South African distribution of powers is highly influenced by the German cooperative government notion, with many concurrent powers and a few exclusive powers. Extensive national legislation in areas of concurrent jurisdiction, the dominance of one party politically, and values of cooperative government have resulted in a largely administrative role for provinces. See Nico Steytler, Republic of South Africa, in 1 A Global Dialogue on FEderalism: Constitutional ORIGins, STRUCTURE, ANd Change IN FEDERAL CoUNTRIES 312, 325-28 (John Kincaid \& G. Alan Tarr ed., 2005).

106. See id. at 328. While not within the scope of this note, political bargaining is just as influential, and likely more influential, than constitutional primacy provisions when considering conflict resolution between the central government and periphery.

107. See SUdAN ConsT., 2005, sched. F.

108. SUDAN CONST., 2005, sched. F. 
initial constitutional division of power and the development of conflict resolution jurisprudence will determine the lasting effect of this unique primacy clause, which does little more than remind courts of the principles they should strive for as they rule on legislative conflicts. ${ }^{109}$ The possibility also remains that Sudan will alter the Sudanese Constitution to follow a more national primacy approach now that South Sudan has seceded.110

\section{India}

Finally, India's Constitution of 1949 contains a primacy clause worth examination. First, one must understand that the Constitution relays a detailed list of national, provincial, and concurrent powers, with residuary powers going to the national legislature. ${ }^{111}$ Interestingly, the Constitution also provides means by which the national legislature can acquire the temporary ability to make law relating to matters on the exclusive list of provincial powers. This temporary ability is granted through special approval of the Council of States (the upper house of the legislature, which represents the states) or if there is a state of emergency. ${ }^{112}$ Additionally, if two or more states agree, those states may consent to relinquish some of their exclusive power for regulation by the national legislature. ${ }^{113}$ It is important to keep this complex system of power distribution, which allows both temporary and permanent subsumption of provincial power, in mind when considering India's primacy clause.

Article 254 creates a default of national primacy in case of conflict between national and provincial law regarding any matter found in the Concurrent List, and, therefore, the provincial law to the extent of

109. The Sudanese federal constitutional structure and division of power creates concentric circles of power, much like the United States. The powers of the provincial legislature and constitutions, especially because of overarching administrative units, cannot conflict with the powers of the national legislature, which are fairly extensive. Lakshman Marasinghe, Constitutional Structures: Lessons from Aceh and The Sudan, 14 ASIA PAC. L. REV. 177, 183-84 (2006).

110. Southern Sudan, as a region, played a major role in the development of the Sudanese Constitution and the agreements that resulted in the 2005 constitution. It will be interesting to see if this primacy clause will remain in the constitution now that South Sudan is a sovereign nation, and there is less of a need to devolve power to maintain unity.

111. See INDIA CONST. arts. 245-248. See generally George Mathew, Republic of India, in 2 A Global Dialogue on Federalism: Distribution of Powers and RESPONSIBILITIES IN FEDERAL SYSTEMS 156 (Akhtar Majeed et al. eds., 2006) for a thorough discussion of the complex constitutional distribution of powers in India.

112. See INDIA CONST. arts. 249-251.

113. INDIA CONST. art. 252. 
repugnancy will be found void. ${ }^{114}$ While Section One of the Article seems to be a typical national primacy clause, Section Two provides conditions that can award primacy to provincial law. If the conflicting provincial law receives the assent of the President and does not prevent the national legislature from subsequently amending or repealing the provincial law, then provincial law will prevail.115 However, this condition for provincial primacy is rarely utilized and repugnant provincial law is usually voided and even subordinated in its own field or in a field of concurrent power. ${ }^{116}$

\section{The European Union}

These examples of conditional primacy clauses vary radically, but they all have elements of subsidiarity within their approaches. This is not surprising, as the purpose of subsidiarity is to strike an effective balance between national and provincial power. Subsidiarity "expresses a preference for governance at the most local level consistent with achieving government's stated purposes." 117 It is a complex and unwieldy doctrinal aspiration that should not be viewed in isolation from the values it is meant to protect. ${ }^{118}$ The European Union serves as the most developed example of a system with explicit subsidiarity requirements; the principle was first spelled out in Article $3 \mathrm{~b}$ of the Maastricht European Community Treaty:

In areas which do not fall within its exclusive competence, the Community shall take action, in accordance with the principle of subsidiarity, only if and in so far as the objectives of the proposed action cannot be sufficiently achieved by the Member States and can therefore, by reason of the scale or effects of the

114. INDIA CONST. art. $254, \S 1$.

115. INDIA CONST. art. $254, \S 2$.

116. See Akhtar Majeed, Republic of India, in 1 A GLobal Dialogue on FEDERalism: Constitutional ORigins, Structure, and Change in Federal Countries 180, 193 (John Kincaid \& G. Alan Tarr eds., 2005). The limited powers given to the states and broad powers given to the Union under the Union and Concurrent Lists should not be thought of as resulting in competing centers of power but as creating co-partners in the task of nation building. Id.

117. Bermann, supra note 66 , at 339.

118. Id. at $339-43$ (listing these values: self-determination and accountability, political liberty, flexibility, preservation of identities, diversity, and respect for internal divisions of component states). 
proposed action, be better achieved by the Community. ${ }^{119}$

The Community could only take action if the member states could not sufficiently achieve the objectives of the action or if the Community could better achieve the action because of scale or effects; and, if actions were taken, they could not go beyond that needed to achieve Treaty objectives. ${ }^{120}$ Treaty chapters, which brought new substantive spheres within Union action, cemented this principle. ${ }^{121}$ The subsidiarity principle was retained by the Lisbon Treaty and embodied in Article 5(3)-(4) Treaty on European Union (TEU) and requires the use of competence to be determined by subsidiarity and proportionality. ${ }^{122}$

The Subsidiarity Protocol of the European Union provides recourse to the European Court of Justice (ECJ) in case of infringement, which would typically be signified by a conflict between the EU and Member State legislation. ${ }^{123}$ There are mechanisms in place now by which a Member State can bring an action to begin ECJ adjudication on behalf of its parliament, but the intensity of judicial review is still in question. ${ }^{124}$ To date, the ECJ has shown a "light" judicial approach to subsidiarity by not typically overturning EU action on the grounds of subsidiarity. ${ }^{125}$ ECJ judicial review of subsidiarity is like walking an incredibly fine line: a review that is too light will eventually leave subsidiarity an empty principle and result in increased fear of centralized power, while a more rigorous approach could entrench the court in a "complex socio-economic calculus concerning the most effective level of government for different regulatory tasks." Rigorous socioeconomic calculus is not a job typically for the judiciary, ${ }^{126}$ especially a supranational judiciary less aware of domestic context.

\footnotetext{
119. Treaty on European Union art. 3(b), Feb. 7, 1992, 1992 O.J. (C 191) 1, amended by Treaty of Lisbon Dec. 17, 2007, 2007 O.J. (C 306) 1. The final paragraph of this article expresses the principle of proportionality: "Any action by the Community shall not go beyond what is necessary to achieve the objectives of this Treaty." Id.

120. CRAIG \& DE BúRCA, supra note 21 , at 94 .

121. See Bermann, supra note 66 , at 346 .

122. CRAIG \& DE BúRCA, supra note 21 , at 95 .

123. Treaty of the Functioning of the European Union art. 263, May 9, 2008, 2008 O.J.

(C 115) 1; CRAIG \& DE BÚRCA, supra note 21, at 98.

124. CRAIG \& DE BÚRCA, supra note 21, at 98.

125. Id.

126. Id. at 99. Estella argues that defining ex ante criteria to limit central intervention will meet little success. "The functional interconnection between regulatory areas, and within the same regulatory area among different regulator levels, makes the task of establishing clear dividing lines difficult." ESTELLA, supra note 24, at 114. "Community intervention, far from being hindered by material subsidiarity could even be encouraged
} 
EU subsidiarity is an ongoing development, an experiment in hopes of attaining a sustainable balance of power, where power is devolved to the maximum extent possible while still developing and maintaining effective central governance. It is the same balancing act faced by every federal system wishing to create a conflict resolution scheme that will maintain the balance achieved by an initial division of powers. EU subsidiarity principles may prove especially informative to nations following a conditional primacy approach, which applies related concepts. Just as it is difficult to determine and enshrine a balance of powers that addresses the social issues that demand federalism, a conditional approach to conflict resolution that stays true to these founding values is just as difficult to enshrine in a constitution. An ex ante attempt to detail primacy conditions is daunting and not always successful in maintaining balance. Despite this difficulty, a conditional approach allows for strategic consideration of the inevitable conflict inherent in federal systems. By pondering and addressing possible future conflicts at the time of constitution making, a conditional primacy clause can provide nuanced and flexible approaches for conflict resolution that are meant to enshrine and further the values originally determinative of federalism and power balance.

Only three of the nineteen federal constitutions with explicit primacy clauses currently conform to the conditional primacy approach: South Africa, Sudan, and India. While the conditional approach to primacy may prove to be more effective within a vacuum, it is the interrelationship between the clause, its provisions, and the rest of the constitution that will be determinative of successful maintenance of the balance of powers. The difficulties here lie in the actual drafting of a clause; it must be effective enough to avoid absolute siphoning of power toward one level of government, but clear enough to avoid ineffectuality. Additionally, a "perfect" primacy clause may prove restrictive if it prevents any subsequent shifts in power dynamics between the nation and provinces.

\section{CONCLUSION}

Just the act of categorizing and creating a typology of primacy clauses alone brings questions and hypotheses to mind. The majority of primacy clauses provide absolute national supremacy in case of conflict. How have these clauses exacerbated the tilting of power toward the central government of those countries? Do these clauses interact

from the optic of the criteria that the Protocol employs materially to define the principle." Id. 
differently with the varied means of dividing power and the degree of specificity afforded to them in the constitution? To what degree does their clarity affect their effectiveness? This Note takes the first step in addressing these questions by creating a terminology and calling attention to a gap in the literature. The next step is to think about what questions need to be asked and attempt to find answers to those questions through thorough case study analysis and comparative research.

Primacy clauses are pertinent to the contemporary world of developing nations and of practical assistance to constitutional consultants. State creation and constitution-drafting processes have increasingly swept the world in wave after wave since 1780,127 with no end in sight. The delicate balance of power that results in effective and fair federal governance is not achieved immediately upon the creation of a novel federal constitution, but only after that constitution stands the tests of time. The internal conflict between national and state legislatures, if not effectively resolved, will shake-possibly fundamentally-the balance that is foundational to federalism. The primacy clause affects the maintenance of that balance over time. While most countries adhere to an absolutist approach that likely contributes to the siphoning of power toward the national government, there are examples of more nuanced conditional approaches that attempt to enshrine and balance values of effectiveness, proportionality, unity, and autonomy.

The conditional primacy clauses of South Africa and Sudan are distinctively different from each other in approach, but both are worth further exploration and consideration by constitution designers of federal systems. South Africa's clause considers conflicts concerning a vast range of matters and thereby provides detailed guidance in an attempt to maintain the original balance of powers between national and provincial legislation. Sudan provides broad value statements to guide courts when they determine the level of governance that would most effectively legislate on the matter at hand. Countries create a division of powers between multiple levels of government for complex and politically motivated reasons. Therefore, the successful maintenance of that delicate balance of power requires a tailored and flexible approach that ensures those foundational reasons for federalism are continually considered. Effective federal governance is realized through conflict, and a constitution should explicitly provide

127. See Jon Elster, Essay, Forces and Mechanisms in the Constitution-Making Process, 45 DUKE L.J. 364, 368-73 (1995) (describing the history of constitution creation). 
mechanisms to effectively weather and realign the balance of power in times of such conflict. 